\title{
THE STUDY OF THE PRODUCTIVITY POTENTIAL OF GRAPE VARIETIES ACCORDING TO THE INDICATORS OF FUNCTIONAL ACTIVITY OF LEAVES
}

\author{
Olena Vasylenko, Tetiana Kondratenko, Oleksandr Havryliuk, Yurii Andrusyk, Vira Kutovenko, \\ Yuliia Dmytrenko, Natalia Grevtseva, Yevheniia Marchyshyna
}

\begin{abstract}
Photosynthetic activity in the leaf of ten grape varieties was studied in the conditions of the northern part of Forest-Steppe of Ukraine. From 2019 to 2020 meteorological data were recorded by the "Meteotrek" meteorological station. The influence of weather conditions of the spring-summer period at the beginning of the vegetation phases, which in 2019 took place on average 12 days earlier than in 2020, was noted. Analysis of changes in the induction of chlorophyll fluorescence (ICF) in leaves revealed the more efficient use of quantum energy of absorbed light by $F_{0}$ in the leaves of most varieties was noted in the phase "the beginning of berry ripening". During the three periods of the study, the varieties Aromatnyj, Zagadka, Ilichevskij rannij, and Kardishah showed a lower content of chlorophyll molecules, which do not have a functional connection with the reaction centers (RC). According to the Fp index the highest intensity of photosynthesis on average for all varieties was observed in the phase "the beginning of ovary growth", the lowest - "the inflorescence is visible". The potential productivity of grape plants determined by the ICF coefficient for all varieties was at a very high level and had a weak or moderate correlation with weather conditions during the growing season. The hydrothermal coefficient and $\Sigma$ act $\mathrm{t} \geq 10{ }^{\circ} \mathrm{C}$ had a weak effect on the efficiency of the light phase of photosynthesis (Ki) and a noticeable one (correlation coefficient $r=0.50-0.69$ ) on the efficiency of dark photochemical processes $(R f d)$ in the leaves of most grape varieties.
\end{abstract}

Keywords: grape variety; chlorophyll fluorescence; phenology; photosynthesis; potential productivity

\section{INTRODUCTION}

The specificity of viticulture industry development is determined by its close connection with the weather and climatic conditions. Due to global climate change, there is a need to assess the response of grape plants to possible changes in agro-climatic growing conditions to use the resources of a particular region more efficiently and increase gross harvest and crop quality (Kovalyshyna et al., 2020a).

Grapes are in demand in many countries around the world. The share of fertile grape plantations in the world is over $3.1 \%$, which is about 12.5 thousand hectares. Most of these plantations are concentrated in the Middle East and European countries (Zheplinska et al., 2019). Ukraine ranks in the world in terms of grape production. According to the FAO, the world grape market is underfunded. According to scientifically sound standards, the annual consumption of grapes per capita should be 2 (Zheplinska et al., 2021). World grape production should reach 14 million tons to ensure such volumes.

The weather has a significant impact on the formation of the grape harvest. Weather conditions change from year to year, which determines the variability of crop values
(Kovalyshyna et al., 2020b; Kolyanovska et al., 2019). The fundamental process, during which the formation of the crop takes place, is photosynthesis (Smetanska et al., 2021). The intensity of photosynthesis in fruit and grape plants is most often investigated by assessing the functional state of their photosynthetic apparatus using the method of induction of chlorophyll fluorescence (ICF). This method determines the sensitivity of the process of photosynthesis to various stress factors, such as temperature, light intensity, the action of toxins, heavy metals, air pollution, and changes in vertical zonation, precipitation, etc. (Mamonova et al., 2018). Studies using the method of ICF and correlation analysis make it possible to determine the potential productivity of grape varieties and establish the level of influence of weather conditions on them. Therefore, this work aimed to determine the level of functional activity of leaves of different grape varieties during the growing season and to establish the influence of weather conditions on the processes of photosynthesis in plants grown in vineyards in the northern part of Ukraine. 


\section{Scientific Hypothesis}

Determining the potential productivity of grape plants in new soil and climatic conditions based on the influence of weather conditions during the growing season on the efficiency of photosynthesis in the leaves will assess the adaptive properties and productivity of plants in the northern forest-steppe of Ukraine for further introduction of the best grape varieties into industrial crops.

\section{MATERIAL AND METHODOLOGY \\ Samples}

Studies to determine the functional state of the leaves of grape plants were conducted in the Laboratory of Plant Physiology and Microbiology of the Institute of Horticulture of the National Academy of Agrarian Sciences of Ukraine (IH NAAS). The objects of the study were ten varieties of grapes selected by NSC "Institute of viticulture and wine-making after V. Ye. Tairov". Plants were planted in the spring of 2017 on rootstock 101-14 'Riparia $\times$ Rupestris' on the territory of the training laboratory (TL) "Fruit and Vegetable Garden" of the National University of Life and Environmental Sciences of Ukraine (Kyiv) according to the scheme $3.0 \times 1.5 \mathrm{~m}$. The soil of the experimental plot is sod-podzolic, light loam with optimal $\mathrm{pH}(6.47-6.81)$, and high content of nitrogen and phosphorus. The soil retention system is black fallow; the plot is irrigated. Grape culture is covered. Meteorological indices for the period 2019 - 2020 were recorded by the "Meteotrek" meteorological station, which is located at a distance of $80 \mathrm{~m}$ from the experimental vineyard, and processed in Excel.

\section{Chemicals}

No chemicals were used.

\section{Biological Material:}

The study used green fully formed leaves of ten varieties of grapes which were on the same side of the row and the leaf blade was evenly lit.

\section{Instruments}

A portable chronofluorometer "Floratest" developed at the Institute of Cybernetics. V. M. Glushkova NAS of Ukraine. The device online registers the fluorescence of the plant leaf. Information in the form of a chlorophyll fluorescence induction curve is displayed on the device displays. This curve reflects the physiological state of the entire chain of photosynthesis and the kinetics of its various links. The shape of this curve and its sections can be used to assess and predict the degree of influence on the plant of both the main environmental factors and endogenous ones.

\section{Laboratory Methods}

Diagnosis of the functional activity of grape leaves was performed with a portable chronofluorometer "Floratest", which monitors the work of Photosystems II (PSII) and chloroplasts (Figure 1). The device registers the "Kautsky curve" (induction changes in fluorescence), the shape of which fully reflects the course of photosynthesis in the chloroplasts of leaves (Brajon et al., 2000). Kautsky effect (induction of chlorophyll fluorescence) is a phenomenon of change in the glow of chlorophyll, which occurs during prolonged illumination of a plant leaf previously adapted to darkness.

During the assessment of the functional state of the photosynthetic apparatus by inductive changes in chlorophyll fluorescence, a set of parameters was used, which allowed us to analyze the changes in photosynthetic processes in the leaves, namely:

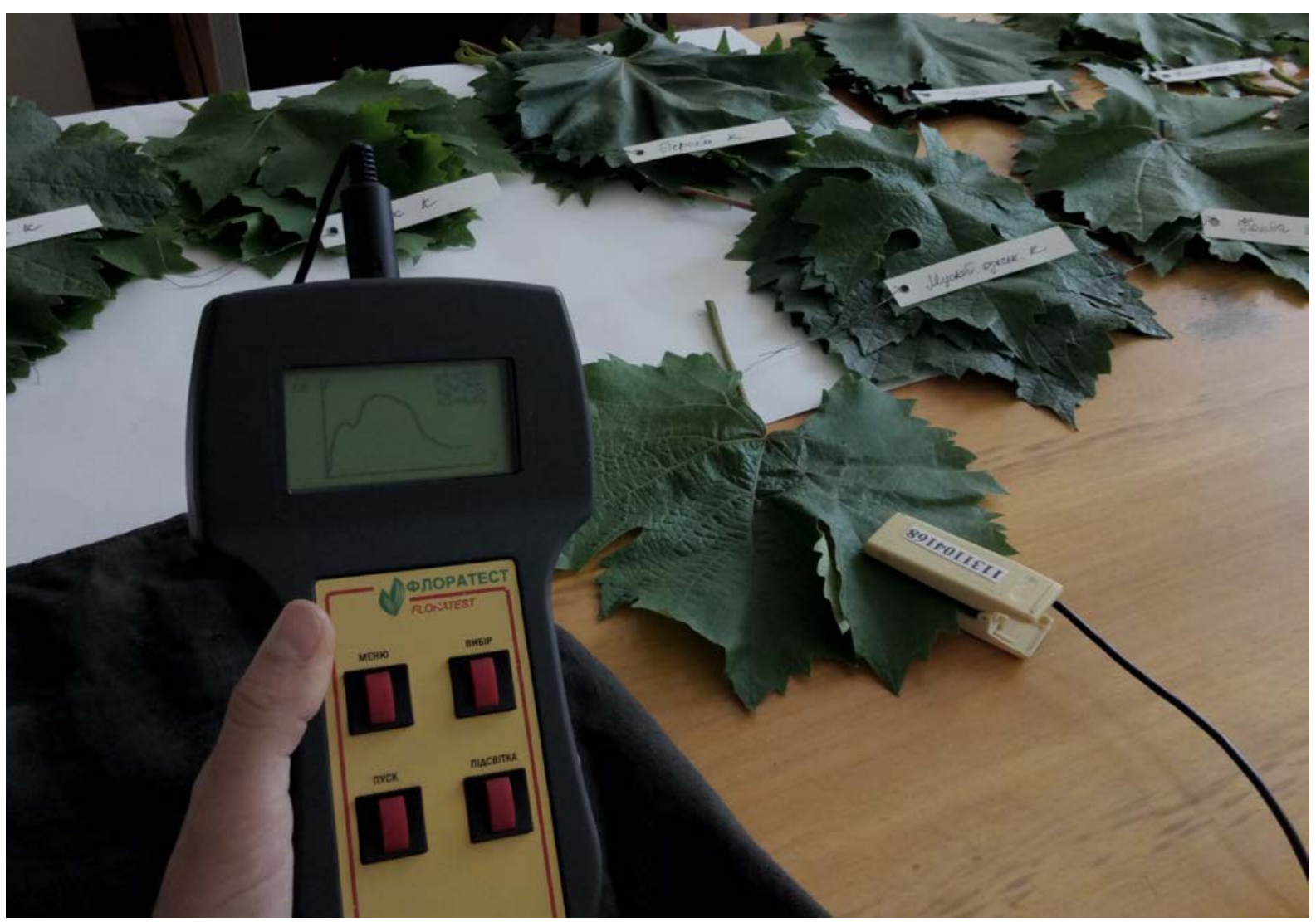

Figure 1 Functional activity research of grape leaves using a portable chronofluorometer "Floratest". 
$F_{0}$ - "background" level of fluorescence; depends on the loss of excitation energy during the migration of the pigment matrix, as well as on the content of chlorophyll molecules that have no functional connection with the reaction centers $(\mathrm{RC})$. At the initial moment $\left(F_{0}\right)$ all the channels of photosynthetic electron transfer are open and the maximum energy of the excited electrons goes to the photosynthetic process.

$F p$ - the maximum value of fluorescence, which characterizes the highest level of fluorescence of chlorophyll $a$ (Chla) and is displayed as a maximum on the induction curve.

Ft - a stationary level, which is characterized by a dynamic equilibrium between the processes that cause an increase in fluorescence and the processes that lead to its decrease.

The following indicators were calculated by the analytical method:

$\mathrm{Ki}$ - coefficient of induction of chlorophyll fluorescence shows the share of chlorophylls involved in photosynthesis, from their total number and determines the efficiency of the light phase of photosynthesis: $\left(F p-F_{0}\right) / F p$;

$R f d$ - coefficient of efficiency of dark photochemical processes or the coefficient of decline fluorescence, which characterizes quantum efficiency of photosynthesis (viability index): ( $F p-F t$ ) / Ft (Havryliuk et al., 2019).

\section{Description of the Experiment}

For integrated assessment of the state of the photosynthetic apparatus by ICF, a green, fully formed, pre-adapted to the darkness grape leaf was placed between the plates of the remote optical sensor of the device "Floratest" and changes in chlorophyll fluorescence were recorded for $4 \mathrm{~min}$. Plant samples (each in five repetitions) - leaves 30 - 35 days of age were analyzed in three phases of grape development: the first - the inflorescence is visible; the second is the beginning of ovary growth; the third is the beginning of berry ripening.

Sample preparation: leaves of grape plants were selected from the middle part of the vine, in the morning from 8 to 9 o'clock. Which are on one side of the row, well lit, and not shaded by other leaves. They were placed in dark plastic bags, without access to light, and after $2-3$ hours analyzed in the laboratory.

Number of samples analyzed: 300 leaves for 2 years. Number of repeated analyses: leaves of 10 grape varieties in five repetitions.

Number of experiment replication: three times during the growing season, for two years.

\section{Statistical Analysis}

Data from the device was transferred to a PC, where it was interpreted by the program "Floratest" in Microsoft Excel 2016.

Using correlation analysis, the strength of the connection between meteorological elements for the years of the field experiment and indices of photosynthesis efficiency in the leaves of the studied grape varieties was calculated. The influence of the factor by the correlation coefficient is weak $\leq 0.29$, moderate: $0.30-0.49$, noticeable: $0.50-$ 0.69 , high: $0.70-0.89$, very high: $0.90-0.99$. Statistical processing was performed in Microsoft Excel 2016 in combination with XLSTAT.

\section{RESULTS AND DISCUSSION}

According to agro-climatic zoning, the study area according to the average long-term data belongs to the northern part of Forest-Steppe (HTI $1.0-1.3$, the sum of active temperatures of $10{ }^{\circ} \mathrm{C}$ and more is $2700{ }^{\circ} \mathrm{C}$ ). Several scientists from Ukraine and Europe were engaged in similar scientific researches, they carried out the scientific work, both in the open and in the closed ground in various climatic zones (Conradie et al., 2019; Malu, Sharma and Pearce, 2017; Schwerz et al., 2017; Alameldin, 2017). Over the years of the field experiment during the growing season, various weather conditions developed, which allowed assessing the degree of their influence on the functional activity of the leaves of grape plants in certain phases of development of the latter. In 2019, during the growing season, the hydrothermal coefficient fluctuated in the range of $0.8-1.2$, the lowest being at the end of summer. The sum of active temperatures of $10{ }^{\circ} \mathrm{C}$ and more $\left(\Sigma\right.$ act $\left.\mathrm{t} \geq 10^{\circ} \mathrm{C}\right)$ during the growing season was $3317{ }^{\circ} \mathrm{C}$. The weather of 2020 differed from 2019 by less heat accumulation in the spring and summer and more precipitation (HTI 1.6 - 3.6). According to $\Sigma$ act $\mathrm{t} \geq 10^{\circ} \mathrm{C}$ the terms of the study were almost the same $\left(2020-3370{ }^{\circ} \mathrm{C}\right)$, which is on average $644^{\circ} \mathrm{C}$ more than the climatic norm.

In 2019, from the beginning of the growing season to the phase "the inflorescence is visible" $\Sigma$ act $\mathrm{t} \geq 10{ }^{\circ} \mathrm{C}$ was $577^{\circ} \mathrm{C}$, in $2020-522{ }^{\circ} \mathrm{C}$, but its accumulation occurred 12 days later, compared with 2019. In the phase "the beginning of ovary growth" $\Sigma$ act $\mathrm{t} \geq 10^{\circ} \mathrm{C}$ was $1300^{\circ} \mathrm{C}$, which in 2019 was recorded 11 days earlier compared to $2020\left(1308{ }^{\circ} \mathrm{C}\right)$. In 2019, from the beginning of the vegetation to the phase "the beginning of berry ripening" $\Sigma$ act $\mathrm{t} \geq 10^{\circ} \mathrm{C}$ was equal to $1906{ }^{\circ} \mathrm{C}$ and occurred 12 days earlier than in $2020\left(1944^{\circ} \mathrm{C}\right)$.

A comparative analysis of precipitation in the years of the study showed that in 2020 in all three terms of measuring the amount of precipitation was higher by 64 , 53, and 48\%, respectively. In May 2020, precipitation was 3.2 times more than in 2019 and 3.1 times more than the climatic norm. June precipitation of 2019 and 2020 accounted for only $62 \%$ of the long-term norm, for July the situation with humidity was also different: in 2020 precipitation was almost the norm - 92\%, and in 2019 only half of the climatic norm. In August, the amount of precipitation in 2019 was $75 \%$, in $2020-45 \%$ of longterm values.

After the onset of light influence on the previously adapted to the dark leaf of the plant, the fluorescence intensity of chlorophyll changes significantly during the measurement period. The time dependence of ICF has the characteristic appearance of a curve with several maxima. The shape of this curve reflects the changes that occur in the photosynthetic apparatus of the plant during its adaptation to different environmental conditions.

According to Kornyeyev (2002), the level of chlorophyll fluorescence emitted by PS II complexes with "open" reaction centers depends on the loss of excitation energy during its migration through the pigment matrix of lightharvesting complexes. 
Table 1 A characteristic of the functional state of grape leaves according to $F_{0}$ and $F_{P}$ (c. u.) NULES of Ukraine, 2019 2020.

\begin{tabular}{lcccccc}
\hline & \multicolumn{9}{c}{$\boldsymbol{F}_{\mathbf{0}}$} & \multicolumn{3}{c}{$\boldsymbol{F}_{\boldsymbol{p}}$} \\
\cline { 2 - 7 } \multicolumn{1}{c}{ Varieties } & \multicolumn{2}{c}{ according to phenological phases } \\
\cline { 2 - 7 } & $\begin{array}{c}\text { inflorescence is } \\
\text { visible }\end{array}$ & $\begin{array}{c}\text { beginning } \\
\text { of ovary } \\
\text { growth }\end{array}$ & $\begin{array}{c}\text { beginning } \\
\text { of berry } \\
\text { ripening }\end{array}$ & $\begin{array}{c}\text { inflorescence } \\
\text { is visible }\end{array}$ & $\begin{array}{c}\text { beginning } \\
\text { of ovary } \\
\text { growth }\end{array}$ & $\begin{array}{c}\text { beginning } \\
\text { of berry } \\
\text { ripening }\end{array}$ \\
\hline Aromatnyj & $264 \mathrm{ab}$ & $238 \mathrm{a}$ & $226 \mathrm{a}$ & $1506 \mathrm{a}$ & $987 \mathrm{a}$ & $1309 \mathrm{a}$ \\
Zagadka & $243 \mathrm{ab}$ & $270 \mathrm{ab}$ & $245 \mathrm{ab}$ & $1520 \mathrm{a}$ & $1166 \mathrm{ab}$ & $1480 \mathrm{ab}$ \\
Ilichevskij rannij & $256 \mathrm{ab}$ & $243 \mathrm{ab}$ & $226 \mathrm{a}$ & $1662 \mathrm{ab}$ & $1208 \mathrm{ab}$ & $1477 \mathrm{ab}$ \\
Kardishah & $253 \mathrm{ab}$ & $269 \mathrm{ab}$ & $230 \mathrm{a}$ & $1600 \mathrm{ab}$ & $1202 \mathrm{ab}$ & $1333 \mathrm{ab}$ \\
Kishmish tairovskij & $269 \mathrm{ab}$ & $282 \mathrm{~b}$ & $274 \mathrm{~b}$ & $1694 \mathrm{ab}$ & $1379 \mathrm{~b}$ & $1558 \mathrm{~b}$ \\
Kometa & $274 \mathrm{~b}$ & $293 \mathrm{bc}$ & $270 \mathrm{~b}$ & $1763 \mathrm{ab}$ & $1302 \mathrm{~b}$ & $1606 \mathrm{~b}$ \\
Muskat odesskij & $235 \mathrm{a}$ & $240 \mathrm{a}$ & $261 \mathrm{~b}$ & $1523 \mathrm{a}$ & $1141 \mathrm{ab}$ & $1474 \mathrm{ab}$ \\
Persej & $286 \mathrm{~b}$ & $272 \mathrm{~b}$ & $251 \mathrm{ab}$ & $1768 \mathrm{~b}$ & $1310 \mathrm{~b}$ & $1541 \mathrm{~b}$ \\
Shkoda & $270 \mathrm{ab}$ & $318 \mathrm{c}$ & $253 \mathrm{ab}$ & $1669 \mathrm{ab}$ & $1347 \mathrm{~b}$ & $1469 \mathrm{ab}$ \\
Yarilo & $272 \mathrm{~b}$ & $274 \mathrm{~b}$ & $254 \mathrm{ab}$ & $1653 \mathrm{ab}$ & $1222 \mathrm{~b}$ & $1461 \mathrm{ab}$ \\
\hline
\end{tabular}

Note: Different letters indicate values that differ significantly according to the $5 \%$ level of significance (for all tables).

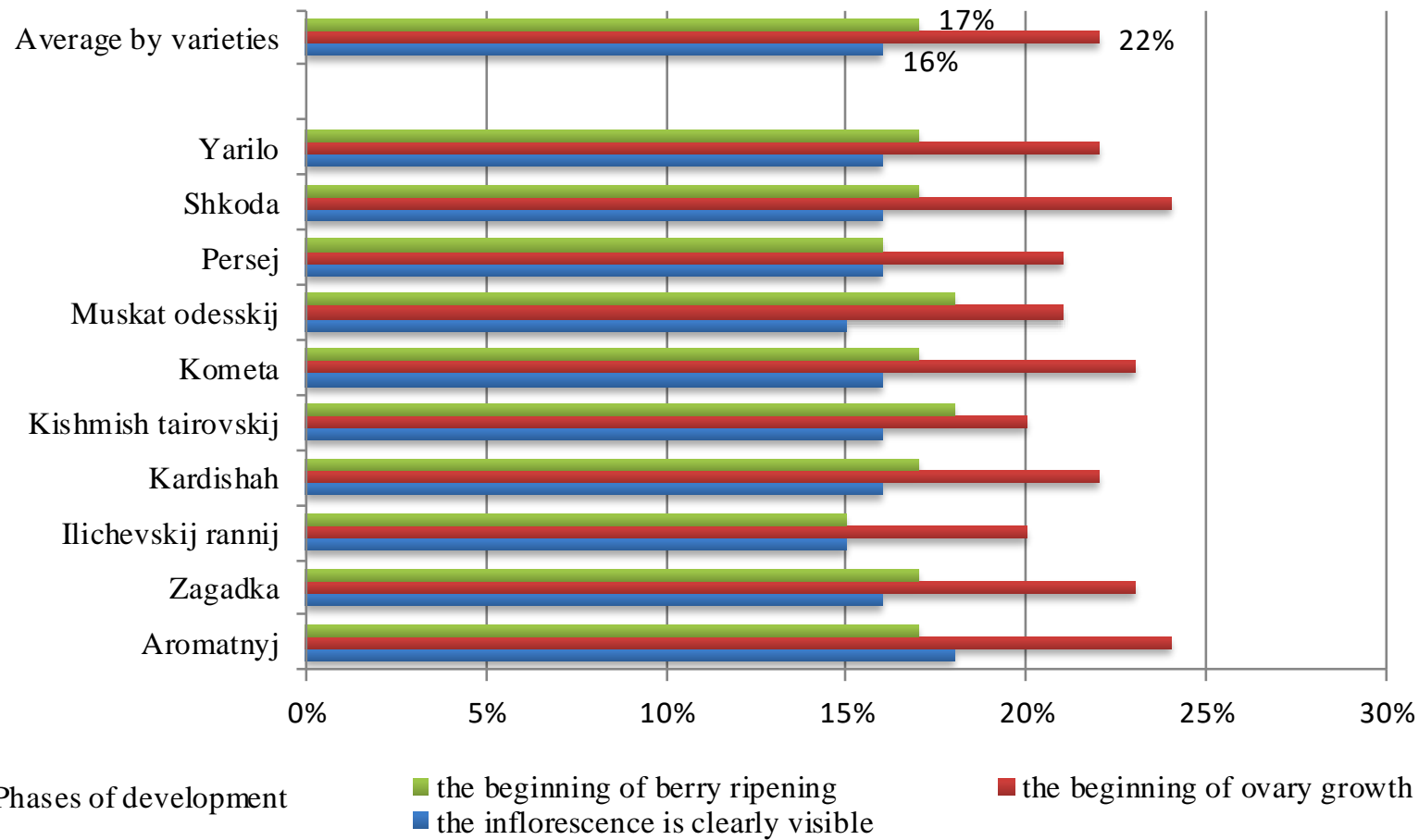

Figure 2 The level of energy use for the synthesis of organic matter $\left(F_{0} / F p\right)$ at different phases of plant development of the studied grape varieties.

In active photosynthesis, when all reaction centers are in the open operating state, in low light conditions, about $3 \%$ of the absorbed light energy is not used in the process of photosynthesis. But the authors of the following scientific papers argue that in active photosynthesis when all reaction centers are in normal light, about $10 \%$ of absorbed light energy is not used in photosynthesis, which can have a significant impact on the yield and quality of grapes (Palamarchuk et al., 2020; Drenjančević et al., 2017). As a rule, in conditions of cultivation favorable for the plant, the value of $F_{0}$ is insignificant which indicates the active use of energy of absorbed light by cells. At different phases of development of grape bushes, the background level of chlorophyll fluorescence in leaves varied in the range of 235 - 286, 238 - 318, and 226 - 274 c. u. (Table $1)$.

The more efficient use of quantum energy of absorbed light by $F_{0}$ in the leaves of most varieties was noted in the phase "the beginning of berry ripening". During the three periods of the study, the varieties Aromatnyj, Zagadka, Ilichevskij rannij, and Kardishah showed a lower content of chlorophyll molecules, which do not have a functional connection with the reaction centers (RC) (Pascale et al., 2017; Martínez et al., 2018). 
Table 2 Characteristics of the functional state of grape leaves according to Ki and $R f d$ (c. u.). NULES of Ukraine, 2019 2020.

\begin{tabular}{lcccccc}
\hline & \multicolumn{9}{c}{ Ki } & \multicolumn{3}{c}{ Rfd } \\
\cline { 2 - 7 } \multicolumn{1}{c}{ Varieties } & \multicolumn{2}{c}{ according to phenological phases } & \\
\cline { 2 - 7 } & $\begin{array}{c}\text { inflorescence is } \\
\text { visible }\end{array}$ & $\begin{array}{c}\text { beginning } \\
\text { of ovary } \\
\text { growth }\end{array}$ & $\begin{array}{c}\text { beginning } \\
\text { of berry } \\
\text { ripening }\end{array}$ & $\begin{array}{c}\text { inflorescence is } \\
\text { visible }\end{array}$ & $\begin{array}{c}\text { beginning } \\
\text { of ovary } \\
\text { growth }\end{array}$ & $\begin{array}{c}\text { beginning } \\
\text { of berry } \\
\text { ripening }\end{array}$ \\
\hline Aromatnyj & $0.822 \mathrm{a}$ & $0.740 \mathrm{a}$ & $0.825 \mathrm{ab}$ & $1.94 \mathrm{a}$ & $1.80 \mathrm{a}$ & $1.83 \mathrm{~b}$ \\
Zagadka & $0.836 \mathrm{a}$ & $0.761 \mathrm{ab}$ & $0.834 \mathrm{ab}$ & $2.64 \mathrm{~b}$ & $1.79 \mathrm{a}$ & $2.09 \mathrm{bc}$ \\
Ilichevskij rannij & $0.844 \mathrm{a}$ & $0.792 \mathrm{~b}$ & $0.842 \mathrm{~b}$ & $2.61 \mathrm{~b}$ & $1.93 \mathrm{~b}$ & $1.94 \mathrm{bc}$ \\
Kardishah & $0.838 \mathrm{a}$ & $0.771 \mathrm{ab}$ & $0.824 \mathrm{a}$ & $2.73 \mathrm{~b}$ & $1.84 \mathrm{ab}$ & $2.01 \mathrm{bc}$ \\
Kishmish tairovskij & $0.841 \mathrm{a}$ & $0,792 \mathrm{~b}$ & $0.823 \mathrm{a}$ & $2.52 \mathrm{~b}$ & $2.01 \mathrm{~b}$ & $1.87 \mathrm{bc}$ \\
Kometa & $0.843 \mathrm{a}$ & $0.771 \mathrm{ab}$ & $0.829 \mathrm{ab}$ & $2.77 \mathrm{~b}$ & $2.18 \mathrm{ab}$ & $2.21 \mathrm{bc}$ \\
Muskat odesskij & $0.845 \mathrm{a}$ & $0.784 \mathrm{~b}$ & $0.823 \mathrm{a}$ & $2.18 \mathrm{ab}$ & $1.50 \mathrm{a}$ & $1.52 \mathrm{a}$ \\
Persej & $0.833 \mathrm{a}$ & $0.788 \mathrm{~b}$ & $0.835 \mathrm{ab}$ & $2.77 \mathrm{~b}$ & $2.02 \mathrm{~b}$ & $2.13 \mathrm{c}$ \\
Shkoda & $0.837 \mathrm{a}$ & $0.756 \mathrm{ab}$ & $0.825 \mathrm{ab}$ & $2.50 \mathrm{~b}$ & $2.04 \mathrm{~b}$ & $1.79 \mathrm{ab}$ \\
Yarilo & $0.831 \mathrm{a}$ & $0.770 \mathrm{ab}$ & $0.824 \mathrm{a}$ & $2.23 \mathrm{ab}$ & $1.79 \mathrm{a}$ & $2.19 \mathrm{c}$ \\
\hline
\end{tabular}

Table 3 Correlation between meteorological elements and intensity of photosynthesis of grape plants (according to Ki and Rfd indices). NULES of Ukraine, 2019 - 2020.

\begin{tabular}{|c|c|c|c|c|c|c|}
\hline \multirow{3}{*}{ Varieties } & \multicolumn{3}{|c|}{ Ki } & \multicolumn{3}{|c|}{$R f d$} \\
\hline & \multicolumn{6}{|c|}{ Meteorological elements } \\
\hline & HTI & $\Sigma$ act $t \geq 10$ & $\Sigma$ precipitation & HTI & $\Sigma$ act $t \geq 10$ & $\Sigma$ precipitation \\
\hline Aromatnyj & 0.19 & 0.22 & 0.46 & 0.53 & -0.12 & 0.30 \\
\hline Zagadka & 0.16 & 0.21 & 0.38 & 0.37 & -0.49 & -0.19 \\
\hline Ilichevskij rannij & 0.16 & 0.19 & 0.36 & 0.52 & -0.55 & -0.07 \\
\hline Kardishah & 0.29 & 0.03 & 0.35 & 0.74 & -0.54 & 0.04 \\
\hline Kishmish tairovskij & 0.38 & -0.17 & 0.23 & 0.41 & -0.63 & -0.36 \\
\hline Kometa & 0.27 & 0.01 & 0.28 & 0.30 & -0.55 & -0.28 \\
\hline Muskat odesskij & 0.36 & -0.14 & 0.25 & 0.50 & -0.60 & -0.29 \\
\hline Persej & 0.03 & 0.36 & 0.35 & 0.51 & -0.51 & -0.18 \\
\hline Shkoda & 0.18 & 0.01 & 0.14 & 0.50 & -0.59 & -0.09 \\
\hline Yarilo & 0.23 & 0.14 & 0.42 & 0.42 & -0.07 & 0.17 \\
\hline
\end{tabular}

Adaptive changes in the structure of the pigment complex to the lighting conditions because the Fp index is the most variable. The values of the maximum value of fluorescence depend on the intensity of the excited radiation and they are proportional to the total number of chlorophylls and inversely proportional to the density of the reaction centers. It is believed that at the point $F p$ at the maximum level of chlorophyll fluorescence photosynthesis is at a minimum one (Kytaiev et al., 2005). Thus, the highest intensity of photosynthesis on average for all varieties was observed in the phase "the beginning of ovary growth", the lowest - "the inflorescence is visible". Analyzing in detail the $F p$ index by varieties, it was found that the intensity of photosynthesis was significantly higher in the second measurement period compared to the first, namely: for the variety Aromatnyj by 34\%; Zagadka - 23\%; Ilichevskij rannij - 27\%; Kardishah - 25\%; Kishmish tairovskij - 18\%; Kometa 26\%; Muskat odesskij - 25\%; Persej - 26\%; Shkoda $19 \%$; Yarilo - 26\%, which in our opinion is due to insufficient insolation in the first measurement period. The process of photosynthesis under such conditions is limited by the intensity of light entering the plant (Lukatkin et al., 2011).

According to long-term studies of the Laboratory of Plant Physiology of the IH NAAS, the optimal level of background fluorescence is not more than $20-25 \%$ of the maximum value of fluorescence $(F p)$. We found that for all studied varieties of grapes pigment complex functions actively in all phases of bush development (Figure 2).

In the phases "the inflorescence is visible" and "the beginning of berry ripening" the index $F_{0} / F p$ fluctuates on the average on grades in the range $-16-17 \%$, in a phase "the beginning of ovary growth" $-22 \%$. We believe that this is due to the large amount of energy expended on the intensive growth of the fruit (ovary).

An effective way to monitor the impact of environmental stress on the plant is a calculated indicator - the fluorescence induction coefficient of chlorophyll $(\mathrm{Ki})$, which shows the share of chlorophylls involved in photosynthesis, their total number and determines the efficiency of the light phase of photosynthesis. According to the obtained data (Table 2), the $K i$ index in the leaves of grape plants in the first and third measurement periods ranged in the same range of $0.822-0.845$ and $0.823-$ 
0.842 c. u. respectively, in the second $-0.740-0.792$ c. u. Studies performed by Lukatkin et al., (2011), indicate a high level of efficiency of photophysical processes near the reaction. Several scientists (Hu et al., 2019; Conde et al., 2018; Kernaghan, Mayerhofer and Griffin, 2017) have been engaged in similar scientific researches and found that the $K i$ index in the leaves of grape plants in the first and third measurement periods ranged in the same range of $0.810-0.838$ and $0.813-0.822$ s. u. respectively, in the second $-0.720-0.762$ s. u.

The value of $K i$ is associated with changes in the efficiency of the process of photochemical quenching of chlorophyll fluorescence. This index of dark-adapted plants reflects the potential quantum efficiency of PS II, used as an indicator of photosynthesis productivity, the optimal value of which for most plant species, under saturating intensity of exciting light, does not exceed 0.83 (Ivanova et al., 2021).

An increase of this index diagnoses the phenomenon of photoinhibition and testifies to the influence of stress factors on plants (He et al., 1996; Sukhenko et al., 2019). At the phase "the inflorescence is visible" for grape leaves Ilichevskij rannij, Kishmish tairovskij, Kometa, Muskat odesskij indicator $K i$ was higher than the optimal value, but among varieties as to the value of $K i$ a significant difference was not found. At the phase of "the beginning of ovary growth," variety Aromatnyj as to this index differed significantly from most varieties. In the third measurement period, a significant difference in the value of $\mathrm{Ki}$ was among varieties Muskat odesskij, Kishmish tairovskij, Yarilo, Kardishah compared to the variety Ilichevskij rannij.

Thus, according to the fluorescence induction coefficient of chlorophyll (Ki), the potential productivity of grape plants of all varieties was at a very high level compared with data obtained by other analysis (Zelenianska, 2009; Havryliuk et al., 2019; He et al., 2018; Bober et al., 2020).

The coefficient of adaptability or "viability index" $(R f d)$ we used to assess the impact of growing conditions on the state of the plant. Reduction of the calculated Rfd to 1.47 1.91 c. u. indicates the negative impact of growth conditions or the possible effect of stress on the efficiency of the Calvin cycle (Lysenko et al., 2013; El Sayed et al., 2019; Shanina et al., 2019). In grape plants at the development phase, "the inflorescence is visible", the average viability index among varieties was 2.49 c. u., at the phase of "the beginning of ovary growth" there was a decrease to 1.89; at the phase "the beginning of berry ripening” - up to 1.96 c. u. Plants were cultivated on a well-lit area, on a vertical trellis, the access of the sun to all parts of the grape bush is very good, so, in our opinion, the efficiency of photosynthetic processes is generally high.

The efficiency of photosynthetic processes by the coefficient of adaptability of the variety Muskat odesskij indicates a low intensity of photochemical processes in the second and third measurement period; the decrease in Rfd was $30.3-31.2 \%$. In our opinion, it is associated with a negative effect of anthracnose on the plant; Muskat odesskij variety is more susceptible than other varieties.
The smallest changes in the viability index $(5.7-7.2 \%)$ were determined for plants of the variety Aromatnyj.

To establish the influence of weather conditions during the growing season on the processes of photosynthesis in grape leaves, we used the indices of hydrothermal coefficient, the sum of active temperatures, the amount of precipitation (Ki index), except for Kishmish tairovskij, Muskat odesskij and Persej, for which a greater influence (correlation coefficient $\mathrm{r}=0.36-0.38$, moderate influence) was noted in comparison with other grape varieties (Table 2).

In general, the potential productivity of grape plants (according to $\mathrm{Ki}$ index) was weakly and moderately dependent on weather conditions during the growing season. Among the meteorological elements, the greatest influence on the efficiency of the light phase of photosynthesis in the leaves of the studied grape plants was the amount of precipitation (moderate).

The influence of weather conditions on the value of the coefficient of adaptability $(R f d)$ was greater than the value of Ki. The high influence of HTI on the efficiency of dark photochemical processes in the leaves of the variety Kardishah, for most varieties of grapes it was noticeable (correlation coefficient $r=0.50-0.69$ ), only for varieties Zagadka, Kishmish tairovskij, Kometa and Yarilo it was moderate (correlation coefficient $r=0.30-0.49$ ). The efficiency of dark photochemical processes in the leaves of most grape varieties significantly $(r=0.50-0.69)$ depended on $\Sigma$ act $\mathrm{t} \geq 10^{\circ} \mathrm{C}$ during the growing season, the least dependence on these factors was observed among the varieties Aromatnyj and Yarilo. The amount of precipitation had a weak effect on the quantum efficiency of photosynthesis in the leaves of most grape varieties, but it had a moderate effect on the efficiency of photosynthesis in the leaves of Aromatnyj and Kishmish tayirovskij varieties.

\section{CONCLUSION}

Analysis of changes in the induction of chlorophyll fluorescence (ICF) of leaves revealed the more efficient use of quantum energy of absorbed light by $F_{0}$ in the leaves of most varieties was noted in the phase "the beginning of berry ripening”. During the three periods of the study, the varieties Aromatnyj, Zagadka, Ilichevskij rannij, and Kardishah showed a lower content of chlorophyll molecules, which do not have a functional connection with the reaction centers (RC). According to the $F p$ index the highest intensity of photosynthesis on average for all varieties was observed in the phase "the beginning of ovary growth", the lowest one was at "the inflorescence is visible" phase. The potential productivity of grape plants by the coefficient of ICF for all varieties was at a very high level and had a weak and moderate correlation with weather conditions during the growing season. The hydrothermal coefficient and $\Sigma$ act $\mathrm{t} \geq 10{ }^{\circ} \mathrm{C}$ had a weak effect on the efficiency of the light phase of photosynthesis and a noticeable one (correlation coefficient $r=0.50-0.69$ ) on the efficiency of dark photochemical processes in the leaves of most grape varieties. Weather conditions during the vegetation in 2019 - 2020 differed from the average long-term data by a greater accumulation of heat (on average by $644^{\circ} \mathrm{C}$ ). The influence of meteorological elements of the spring-summer 
period on the onset of the vegetation phases, which in 2019 took place on average 12 days earlier than in 2020, was noted.

These data show that despite the differences in the onset of the vegetation phases and weather conditions during 2019 and 2020, the processes of photosynthesis in grape leaves are at a high level. That indicates a high potential for plant adaptation to the conditions of the northern part of the Forest-Steppe of Ukraine.

In conditions of local and global climate change, it is important to study the adaptive properties of plants to new soil and climatic conditions. In the future, it will allow expanding and changing the areas of cultivation of grapes plants. So that to provide with enough grapes, the population of Ukraine and the world.

\section{REFERENCES}

Alameldin, A. 2017. Comparative study between dietary supplementation of grape pomace and vitamin $\mathrm{E}$ as antioxidant on some productive, reproductive and physiological performance of male and female aged Inshas strain chickens. Egyptian Poultry Science Journal, vol. 37, no. 3, p. 855-872. https://doi.org/10.21608/epsj.2017.7736

Bober, A., Liashenko, M., Protsenko, L., Slobodyanyuk, N., Matseiko, L., Yashchuk, N., Gunko, S., Mushtruk, M. 2020. Biochemical composition of the hops and quality of the finished beer. Potravinarstvo Slovak Journal of Food Sciences, vol. 14, no. 1, p. 307-317. https://doi.org/10.5219/1311

Brajon, O. V., Korneev, D. Y., Snegur, O. O., Kitaev, O. I. 2000. Instrumental study of the photosynthetic apparatus using chlorophyll fluorescence induction. Methodical instructions for students of biological faculty. Kyiv, Ukraine : Kyiv University Publishing and Printing Center, 15 p.

Conde, A., Neves, A., Breia, R., Pimentel, D., Dinis, L. T., Bernardo, S., Moutinho-Pereira, J. 2018. Kaolin particle film application stimulates photoassimilate synthesis and modifies the primary metabolome of grape leaves. Journal of plant

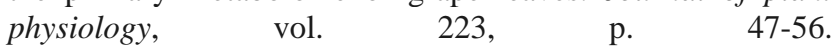
https://doi.org/10.1016/j.jplph.2018.02.004

Conradie, B., Piesse, J., Vink, N., Thirtle, C. 2019. South African wine grape production, 2005 - 2015: regional comparisons of scale and technical efficiencies and total factor productivity. Agrekon, vol. 58, no. 1, p. 53-67. https://doi.org/10.1080/03031853.2018.1537190

Drenjančević, M., Jukić, V., Zmaić, K., Kujundžić, T., Rastija, V. 2017. Effects of early leaf removal on grape yield, chemical characteristics, and antioxidant activity of grape variety Cabernet Sauvignon and wine from eastern Croatia. Acta Agriculturae Scandinavica, Section B-Soil \& Plant Science, vol. 67, no. 8, p. 705-711. https://doi.org/10.1080/09064710.2017.1332238

El Sayed, A. I., El-Hamahmy, M. A. M., Rafudeen, M. S., Ebrahim, M. K. H. 2019. Exogenous spermidine enhances expression of Calvin cycle genes and photosynthetic efficiency in sweet sorghum seedlings under salt stress. Biol. Plant, vol. 63, p. 511-518. https://doi.org/10.32615/bp.2019.046

Havryliuk, O. S., Kondratenko, T. E., Kytaiev, O. I. 2019. Diagnostics of the functional state of plants of colonial varieties of apple. Plant and soil science, vol. 10, no. 1, p. 780. https://doi.org/10.31548/agr2019.02.070

He, J., Chee, C. W., Goh, C. J. 1996. Photoinhibition of Heliconia under natural tropical conditions: the importance of leaf orientation for light interception and leaf temperature.
Plant, Cell \& Environment, vol. 19, no. 11, p. 1238-1248. https://doi.org/10.1111/j.1365-3040.1996.tb00002.x

He, L., Yu, L., Li, B., Du, N., Guo, S. 2018. The effect of exogenous calcium on cucumber fruit quality, photosynthesis, chlorophyll fluorescence, and fast chlorophyll fluorescence during the fruiting period under hypoxic stress. BMC plant biology, vol. 181, p. 1-10. https://doi.org/10.1186/s12870$\underline{018-1393-3}$

Hu, R., Zhang, Z., Lin, L., Liao, M. A., Tang, Y., Liang, D., Ren, W. 2019. Intercropping with hyperaccumulator plants decreases the cadmium accumulation in grape seedlings. Acta Agriculturae Scandinavica, Section B-Soil \& Plant Science, vol. 69, no. 4, p. 304-310. https://doi.org/10.1080/09064710.2018.1564786

Ivanova, I., Serdiuk, M., Malkina, V., Bandura, I., Kovalenko, I., Tymoshchuk, T., Tonkha, O., Tsyz, O., Mushtruk, M., Omelian, A. 2021. The study of soluble solids content accumulation dynamics under the influence of weather factors in the fruits of cherries. Potravinarstvo Slovak Journal of Food Sciences, vol. 15, no. 1, p. 350-359. https://doi.org/10.5219/1554

Kernaghan, G., Mayerhofer, M., Griffin, A. 2017. Fungal endophytes of wild and hybrid Vitis leaves and their potential for vineyard biocontrol. Canadian Journal of Microbiology, vol. 63, no. 7, p. 583-595. https://doi.org/10.1139/cjm-2016$\underline{0740}$

Kolyanovska, L. M., Palamarchuk, I. P., Sukhenko, Y., Mussabekova, A., Bissarinov, B., Popiel, P., Mushtruk, M. M., Sukhenkko, V., Vasuliev, V., Semko, T., Tyshchenko, L. 2019. Mathematical modeling of the extraction process of oilcontaining raw materials with pulsed intensification of heat of mass transfer. Proceedings of SPIE - The International Society for Optical Engineering, 25 p. https://doi.org/10.1117/12.2522354

Kornyeyev, D. 2002. Informational possibilities of the method of chlorophyll fluorescence induction. Kiev, Altpres, $188 \mathrm{p}$.

Kovalyshyna, H., Dmytrenko, Y., Makarchuk, O., Slobodyanyuk, N., Mushtruk, M. 2020a. The donor properties of resources resistance against the exciter of wheat rust wheat. Potravinarstvo Slovak Journal of Food Sciences, vol. 14, no. 1, p. 821-827. https://doi.org/10.5219/1427

Kovalyshyna, H., Dmytrenko, Y., Tonkha, O., Makarchuk, O., Demydov, O., Humenyuk, O., Kozub, N., Karelov, A., Sozinov, I., Mushtruk, M. 2020b. Diversity of winter common wheat varieties for resistance to leaf rust created in the V. M. Remeslo Myronivka Institute of Wheat. Potravinarstvo Slovak Journal of Food Sciences, vol. 14, no. 1, p. 1001-1007. https://doi.org/10.5219/1447

Kytaiev, O., Klochan, P., Romanov, V. 2005. Portatyvnyi hronofluorometr dlia ekspres-diagnostyky fotosyntezu 'Floratest' (A portable device for the express diagnostics of photosynthesis - fluorometer 'Floratest'). Zb. dop. konf. zvitu z kompleksnoi programy fundamentalnykh doslidzhen NAN Ukrainy u galuzi sensornykh system ta tekhnologiy (2-3 liutogo 2005 r., Kyiv) (Proceedings of conference reports on the integrated program of fundamental researches of NAS of Ukraine in the field of sensor systems and technologies (2-3 February 2005, Kyiv), Kyiv, 59 p. (in Ukraine).

Lukatkin, A. S., Rewin, V. V., Bashmakov, D. I., Krendeleva, T. E., Antal, T. K., Rubyn, A. B. 2011. The ecological assessment of the woody plants state of Saransk by chlorophyll fluorescence). Povolzhskiy Journal of Ecology, vol. 1, p. 87-92.

Lysenko, V. S., Varduni, T. V., Sowyer, V. G., Krasnov, V. P. 2013. The chlorophyll fluorescence of plants as indicators 
of environmental stress: the theoretical foundations of the method. Fundamental research. Biological sciences, vol. 4, p. 112-120.

Malu, P., Sharma, U., Pearce, J. 2017. Agrivoltaic potential on grape farms in India. Sustainable Energy Technologies and Assessments, vol. 23, p. 104-110. https://doi.org/10.1016/j.seta.2017.08.004

Mamonova, R. Yu., Kytaiev, O. I., Shykhalieieva, H. M., Slyusar, S. I., Kolesnyk, Yu. S. 2018. Funktsionalna diahnostyka prystosovanosti introdukovanykh vydiv rodu snizhnoiahidnykiv (Symphoricarpos duhamel) v umovakh mista Kyieva (Functional diagnostics of adaptability of introduced species of the genus snowberry (Symphoricarpos duhamel) in Kyiv city conditions). Scientific reports of NULES of Ukraine, vol. 1, no. 71, p. 1-22. (in Ukrainian). https://doi.org/10.31548/dopovidi2018.01.010

Martínez, M. M., Ortega, R., Janssens, M., Fincheira, P. 2018. Use of organic amendments in table grape: effect on plant root system and soil quality indicators. Journal of soil science and plant nutrition, vol. 18, no. 1, p. 100-112. https://doi.org/10.4067/S0718-95162018005000501

Palamarchuk, I., Mushtruk, M., Sukhenko, V., Dudchenko, V., Korets, L., Litvinenko, A., Deviatko, O., Ulianko, S., Slobodyanyuk, N. 2020. Modelling of the process of vybromechanical activation of plant raw material hydrolysis for pectin extraction. Potravinarstvo Slovak Journal of Food Sciences, vol. 14, no. 1, p. 239-246. https://doi.org/10.5219/1305

Pascale, A., Vinale, F., Manganiello, G., Nigro, M., Lanzuise, S., Ruocco, M., Lorito, M. 2017. Trichoderma and its secondary metabolites improve yield and quality of grapes. Crop protection, vol. 92, p. 176-181. https://doi.org/10.1016/j.cropro.2016.11.010

Shanina, O., Galyasnyj, I., Gavrysh, T., Dugina, K., Sukhenko, Y., Sukhenko, V., Miedviedieva, N., Mushtruk, M., Rozbytska, T., Slobodyanyuk, N. 2019. Development of gluten-free non-yeasted dough structure as factor of bread quality formation. Potravinarstvo Slovak Journal of Food Sciences, vol. 13, no. 1, p. 971-983. https://doi.org/10.5219/1201

Schwerz, F., Caron, B., Elli, E., Eloy, E., Schmidt, D., Stolzle, J. R., Trevisan, R. 2017. The high density of plants increases the radiation use efficiency of photosynthetically active seedlings of Japanese grape ('Hovenia dulcis'). Australian Journal of Crop Science, vol. 11, no. 1, p. 50-54.

Smetanska, I., Tonkha, O., Patyka, T., Hunaefi, D., Mamdouh, D., Patyka, M., Bukin, A., Mushtruk, M., Slobodyanyuk, N., Omelian, A. 2021. The influence of yeast extract and jasmonic acid on phenolic acids content of in vitro hairy root cultures of Orthosiphon aristatus. Potravinarstvo Slovak Journal of Food Sciences, vol. 15, no. 1, p. 1-8. https://doi.org/10.5219/1508

Sukhenko, Y., Mushtruk, M., Vasyliv, V., Sukhenko, V., Dudchenko, V. 2019. Production of pumpkin pectin paste. In Ivanov, V. Trojanowska, J., Machado, J., Liaposchenko, O., Zajac, J., Trojanowska, J., Edl, M., Peraković, D. Advances in Design, Simulation and Manufacturing II. Switzerland : Springer, Cham, p. 805-812. ISBN 978-3-030-22364-9. https://doi.org/10.1007/978-3-030-22365-6_80

Zelenianska, N. M. 2009. Induction of fluorescence of grape leaves under stressful environmental conditions). Bulletin of the Central Executive Committee of the APV of the Kharkiv region, vol. 6 , p. $70-80$.

Zheplinska, M., Mushtruk, M., Vasyliv, V., Deviatko, O. 2019. Investigation of the process of production of crafted beer with spicy and aromatic raw materials. Potravinarstvo
Slovak Journal of Food Sciences, vol. 13, no. 1, p. 806-814. https://doi.org/10.5219/1183

Zheplinska, M., Mushtruk, M., Vasyliv, V., Sarana, V., Gudzenko, M., Slobodyanyuk, N., Kuts, A., Tkachenko, S., Mukoid, R. 2021. The influence of cavitation effects on the purification processes of beet sugar production juices. Potravinarstvo Slovak Journal of Food Sciences, vol. 15, no. 1, p. 18-25. https://doi.org/10.5219/1494

\section{Funds:}

This research received no external funding.

\section{Acknowledgments:}

This study is a part of the PhDs Thesis of Olena Vasylenko. The authors would like to thank for its support to the study to the Department of Horticulture them Prof. V. L. Symyrenko of National University of Life and Environmental Sciences of Ukraine (Kyiv) and to the Laboratory of Plant Physiology and Microbiology of Institute of Horticulture of the National Academy of Agrarian Sciences of Ukraine (Kyiv).

\section{Conflict of Interest:}

The authors declare no conflict of interest.

\section{Ethical Statement:}

This article does not contain any studies that would require an ethical statement.

\section{Contact Address:}

*Olena Vasylenko, National University of Life and Environmental Sciences of Ukraine, Agrobiological Faculty, Department of Horticulture them Prof. V. L. Symyrenko, Heroiv Oborony Str., 12 A, Kyiv, 03041, Ukraine, Tel.: +38(099)712-53-46,

E-mail: elena vasylenko@ukr.net

ORCID: https://orcid.org/0000-0002-9192-8167

Tetiana Kondratenko, National University of Life and Environmental Sciences of Ukraine, Agrobiological Faculty, Department of Horticulture them Prof. V. L. Symyrenko, Heroiv Oborony Str., 12 A, Kyiv, 03041, Ukraine, Tel.: +38(067)326-03-26,

E-mail: kondratenko.pv@gmail.com

ORCID: https://orcid.org/0000-0003-0519-568X

Oleksandr Havryliuk, National University of Life and Environmental Sciences of Ukraine, Agrobiological Faculty, Department of Horticulture them Prof. V. Symyrenko, Heroiv Oborony Str., 12 A, Kyiv, 03041, Ukraine, Tel.: +38(067)800-10-23,

E-mail: o.havryliuk@nubip.edu.ua

ORCID: https://orcid.org/0000-0002-4551-6727

Yurii Andrusyk, National University of Life and Environmental Sciences of Ukraine, Agrobiological Faculty, Department of Horticulture them Prof. V. L. Symyrenko, Heroiv Oborony Str., 12 A, Kyiv, 03041, Ukraine, Tel.: +38(097)886-31-46,

E-mail: yuran@nubip.edu.ua

ORCID: https://orcid.org/0000-0003-0965-7458

Vira Kutovenko, National University of Life and Environmental Sciences of Ukraine, Agrobiological Faculty, Department of Vegetable and Greenhouse, Heroiv Oborony Str., 12 A, Kyiv, 03041, Ukraine, Tel.: +38(068)002-81-59, 
E-mail: virakutovenko@gmail.com

ORCID: https://orcid.org/0000-0003-0473-1727

Yuliia Dmytrenko, National University of Life and Environmental Sciences of Ukraine, Agrobiological Faculty, Department of Genetics, Plant Breeding and Seed Production them Prof. M. O. Zelensky, Heroiv Oborony Str., 13, Kyiv, 03041, Ukraine, Tel.: +38(098)78-30-971,

E-mail: dmitrenko.yuliia@gmail.com

ORCID: https://orcid.org/0000-0002-3942-9125

Natalia Grevtseva, Kharkov State University of Food Technology and Trade, Department of International ECommerce and Hotel and Restaurant Business, Maidan Svobody str., 6, Kharkiv, 61022, Ukraine Tel.: +38 (057) 707-53-06,

E-mail: nataver@yandex.ru

ORCID: https://orcid.org/0000-0001-5380-182X
Yevheniia Marchyshyna, National University of Life and Environmental Sciences of Ukraine, Mechanical and Technological Faculty, Department of Occupational Safety and Environmental Engineering, Heroyiv Oborony str., 12, studying building No. 11, Kyiv, 03041, Ukraine Tel.:+38(098)344 48 37,

E-mail: marchyshyev@gmail.com

ORCID: https://orcid.org/0000-0001-8842-186X

Corresponding author: * 